\title{
CONSTRUCTION OF GRAPHICS IN CHEMISTRY; AN ESSENTIAL COMPETENCE IN INVESTIGATIVE ACTIVITIES
}

\author{
Dirceu D. D. Souza, Karen C. Weber, \\ Federal University of Paraíba, João Pessoa, Brazil
}

\author{
Agnaldo Arroio \\ Faculty of Education, University of Sao Paulo, Sao Paulo, \\ Brazil
}

\begin{abstract}
Teaching processes that promote knowledge integration must consider the relevance of graphical literacy, an essential competence to investigative activities in natural science education. The aim of this study is to analyze the treatment given to the domain of constructing graphics in the official documents related to scholar curriculum in Brazil and to debate it at the light of classroom practices. So, the recent literature on the topic is analyzed, as well as Brazilian official pedagogical orientations. Also, an activity on graphical construction was proposed to high school students and a teacher was interviewed. The results obtained indicate a twilight zone for graphical construction in the official documents, which extends to teaching training and reflects into classroom practices, creating a vicious circle composed by the incongruence in the orientations, limitations in teaching training and therefore in students' learning, which demonstrate a heuristic and a superficial vision of graphical construction when solving Chemistry problems. The implications of these results point out the urge to broaden this debate in order to include this topic in teaching training undergraduate programs, besides emphasizing the exploration of this issue in the classroom.
\end{abstract}

Key words: chemistry teaching, construction of graphics, graphical literacy.

\section{Introduction}

Investigative activities in the Chemistry classroom demand from the teacher the mastery and appropriation of elements of graphical literacy, and from the students, the demonstration of knowledge on these elements along their practices. One of the common practices in the classroom is the production of scientific genres related to chemical education which are populated by images exhibiting their functionalities and relations to the written word. Indeed, graphics, for their unique nature and richness of information, represent a substantial relevance in these visual representations able to support texts.

In particular, graphics as an object of visual representations in its aspects of construction, reading and interpretation have been targets of recent studies which show that students usually have a superficial understanding on certain representations of mathematical objects, being limited to plot data among two axes (Postigo \& Pozo, 1999; Camargo Filho, Laburu, \& Barros, 2011), i.e., students follow the trends of retain a major focus on 
data and textual information, but at the moment they are requested to transcript a phenomenum and build a representation model for a given situation, they might have difficulties to execute such task (Kintsch, 1998; León, 1999; Dias de Souza, Moreira, \& Arroio, 2012a).

In order to teach maximizing the levels of proficiency in competences and abilities to face evaluation situations and also to make students aware of their role in society and in social dimensions of science and technology, something that goes beyond the abstract conceptual frame is required, enabling them to engage into social and political debates about these issues (Secretaria Estadual de Educação/São Paulo [SEE/SP], 2010); (Merino \& Cerezo, 2012; Bybee, 2013).

Lemke (1998a) emphasizes that it is important to learn not only the scientific language, but also about language itself and this implicates on the intellectual transit between the domains of broad scientific literacy, where the representations of mathematical objects such as symbols, graphics and charts (Duval, 2009), - the so-called graphical literacy, gains special contours on multimodal investigative projects (Dias De Souza, Moreira, \& Arroio, 2012a) in Chemistry, in which students are supposed to construct graphics from data collected during experimental activities, in the search for making inferences that would be visualized in the Cartesian plane.

In the discussion about the importance of diverse semiotic systems' representations, Duval (2009) declares that the conceptual understanding, differentiation and domain of different reasoning forms, and the hermeneutic and heuristic interpretations of enunciations are closely related to immediate mobilization and articulation of several records of semiotic representation.

Chemists have come up with symbolic systems highly specialized such as chemical equations, molecular structure diagrams, concentration charts and 3D computational molecular models to represent the molecular phenomena they study on laboratories (Crosland, 1962); and to use them to communicate knowledge and information to their peers (Kozma, Chin, Russell, \& Marx, 1997).

In the specific context of Chemistry and its technologies, the studies are based on making sense from the invisible and untouchable, since those phenomena occur at the molecular level which is not accessible to direct perception (Kozma \& Russel, 1997), therefore chemistry is intrinsically a field of representational and symbolic nature, understood as the skillful study of symbolic transformations applied to graphical objects (Hoffmann \& Laszlo, 1991).

Harrison and Treagust (2000) point out that mathematical models are the most appreciated by scientists, since their different forms of modelling and representations, such as equations and graphics, facilitate the correlation between variables and tend to accomplish a high-priority role on the explanations since they are more plausible, parsimonious, generalisable and useful, being causal and predictive.

Chemists concerned with chemical education also employ these representations to communicate information to students, which can be observed in the images drawn in the blackboard used in classrooms and didactic books fulfilled with tables, charts, schemes and equations along words, pictures and illustrations.

The recent literature in the field of chemical education emphasizes that Sciences, and particularly Chemistry, make a wide use of representations that are idealized or simplified to be understood in the macroscopic world (Mortimer, 1998; Chassot, 2003), by means of symbols, formulas, codes or even graphical models, indicating that the development of such kind of competences and capabilities has a vital importance to learn Chemistry. 
Graphics constitute a significant part of this universal symbolism, since they facilitate the representation of numeric and quantitative relations between variables (Postigo \& Pozo, 2000), revealing itself as an effective way for the circulation of descriptive and analytical information, which allow the reader to instantly comprehend the concepts under study. Moreover, in Natural Sciences, graphical representations in the Cartesian plane abbreviate, reorder and equally expose the implicit information in phenomena, clarifying archetypes of covariation between measurements, enabling the construction of inferences (Garcia Garcia, 2005; Lemke, 1998b; Bastide, 1990; Anderson \& Helstrup, 1993; Schnotz \& Banert, 2003).

Additionally, the significance of graphical literacy, and specifically the construction of graphics in Chemistry, is based on the idea that the context in this field strongly differs from other contexts (Leinhardt, Zaslavsky, \& Stein, 1990), mainly with respect to the situational facet (Giordan, 2008), during the development of projects in Chemistry, in which, for instance, the unities employed are related exclusively to Chemistry Science and Technology involved in the task.

Therefore, the literature indicates that graphic construction is a plausible option as content to be studied at schools, and it must be in all disciplines, since it promotes connections inter- and intra-themes, contributes to the processes of abstraction, comparison and inference, and above all, organize data in the description of phenomena.

However, despite its importance, the investigations undertaken in the last fifteen years have focused on how these representations are interpreted or assimilated by students (Camargo Filho, Laburu, \& Barros, 2011), which limits the degree of understanding comprisement of the cognitive processes involved in this issue, even though several studies point out to the need of broaden graphical literacy (Roth, 2002; Postigo \& Pozo, 1999; Postigo \& Pozo, 2000; Nass, 2008), to which the need to expand the knowledge about restrictions exhibited by high school students in the construction of such representations in chemistry classes has to be added.

Other aspect of this issue is that the new teaching technologies supported by computers and audiovisual resources have been increasingly used in the classroom to represent chemical phenomena in new forms (Illman, 1994; Giordan, 2008; Barro, Ferreira \& Queiroz, 2008; Mello, 2009; Arroio, 2011), although questions of general order and a more elementary nature still persist, such as: how students in Chemistry classes understand the representations with which the phenomena are revealed? Are these students capable of constructing these representations when data are provided? Do the students construct meanings in the way teachers intend to?

One question in particular has drawn attention during labor in the classroom: do the students of elementary/middle/high school are able to construct graphics from data obtained in investigative activities?

Year after year, it has been found in students many restrictions to this task, leading us to organize moments intended to basic orientations about the topic of graphic construction, in an attempt to overcome this challenge. This recurrent fact has guided us to search for explanations that could give us directions to find a possible solution to be incorporated in the annual planning of the Chemistry discipline.

After informal discussions with high school students and Math teachers, realized that the topic of graphic construction deserved a deeper study, since it is known its effects, exposed by restrictions observed in the resolution of activities produced by students, but not an enlargement of this spectrum related to its possible origins.

Initially, it hypothesizes that the orientations contained in official curriculum documents that suggest the contents to be selected in the composition of scholar planning, 
as well as the form of execution of contents involving the construction of graphics, in the disciplines of the fields of Math and Natural Sciences, has an implication on the effects observed in the final results of graphic construction during the resolution of problems in investigative activities conducted in Chemistry classes.

\section{Method}

This work was organized in three main vectors: i) execution of a task of graphic construction by high school students; ii) analysis of Brazilian High School Curriculum Orientations and the Official Curriculum from the State of Sao Paulo Secretary of Education (SEE/SP) - Math and Natural Sciences; iii) an interview with a Math teacher.

The criteria to organize these procedures were taken, interpreted and analyzed from the selection of some of the main references on the field (Leinhart, Zaslavsky \& Stein, 1990; Postigo \& Pozo, 1999; Postigo \& Pozo, 2000; De Vries \& Lowe, 2010; Boucheix, Lowe, Ainsworth, Betrancourt \& De Vries, 2012; Betrancourt, Ainsworth, De Vries, Boucheix \& Lowe, 2012; Dias De Souza, Moreira, \& Arroio, 2012b). Table 1 contains the terms and/or concepts associated to the construction of graphics obtained from the literature.

Table 1. Concepts and/or terms associated to the construction of graphics.

\begin{tabular}{|l|l|}
\hline Concepts and/or terms & Description \\
\hline Construction of graphics & $\begin{array}{l}\text { The action of present a visual representation of data or numeric } \\
\text { values }\end{array}$ \\
\hline Axes & Two perpendicular directed lines representing the Cartesian plane \\
\hline Scale & Refers to the proportionality between two sets of numeric values \\
\hline Variable & Different values of some property or parameter \\
\hline Magnitude & Refers to the relations among properties \\
\hline Domain of a function & The independent variable \\
\hline Image of a function & The dependent variable \\
\hline
\end{tabular}

From these concepts and with the aid of a Chemistry teacher of a public school at the city of Sao Paulo, a task of graphic construction was organized and applied to 63 second year high school students from different classes. This task consisted in constructing a XY scatter plot in graph paper, from the data provided in a table reporting the variation of density as a function of temperature. In order to assess students' comprehension, two complementary questions were proposed:

a) Explain the reason why the variables temperature and density are assigned to their respective axes (it was expected that students could express the relation between these variables by means of a mathematical function and define which one is the dependent and which is the independent variable).

b) Justify the use of the chosen scale relating the $x$ and $y$ sets of values (it was expected that the students would refer the need to establish the proportionality between the two sets of values, in order to provide a suitable visualization and interpretation of the curve).

Additionally, students answered the following questions: 
1) In which moment of your education and in which discipline(s) you were taught to construct graphics?

2) How do you construct graphics?

The analyses of official documents were undertaken on the basis of the criteria listed in Box 1, as well as the semistructured interview, which was composed by oriented questions that started by the identification and qualification of the teacher interviewed, her conceptions about the values of images and words, the degree of accordance with the domain of images in all spheres of contemporary society, the formal study of official documents in her workplace and the use of these documents for scholar planning, the use of diagnostic evaluations to organize this planning, the insertion of the topic of graphic construction on this planning, the usual procedure to teach construction of graphics, the exploration of interdisciplinary issues involving Chemistry and Math concerning construction of graphics and if the construction of graphics is a topic systematically treated considering the parameters listed in Box 1.

The graphics constructed by students were analyzed according to the concepts listed in Table 1. The discursive outcomes were evaluated according to an adaptation of the discursive textual analysis, which originally is constituted by three steps: unitarization, categorization and communication (Moraes \& Galiazzi, 2007).

\section{Results and Discussion}

\section{The Construction of Graphics by High School Students}

The characterization of the graphics produced by students has a central role in the planning and organization of activities in the Chemistry classroom, since it orients teachers towards possible challenges to be faced along the whole high school course. Some facts that deserve special attention from the teacher are the cases in which the student is not aware of the nature of the suitable kind of paper to be used in graphic construction, or even the need to include a title, which put in evidence two putative hypotheses: the non internalization of graphics as a representation of a given phenomenon, $i$. e., graphics are only a place to plot numbers as a mechanical action resulting from an anachronistic moment experienced in basic math classes; or that the reader is the teacher, who possesses the knowledge of what that representation refers (Dias de Souza, Moreira \& Arroio, 2012b).

In the graphics constructed by the students, three patterns of justifications were found for the assignment of variables to the $x$ and $y$ axes: (i) the description of variables, reflecting the common sense of $\mathrm{x}$ being the temperature and $\mathrm{y}$ being the density; (ii) the ease of graphic's reading (and of construction, as a consequence) and for a better visualization of the curve; and (iii) the fact that graphics represent the relation between two variables, although without making clear the condition of dependence between them (image and domain of a function).

These results reinforce our hypothesis related to the way students think when they are constructing graphics, $i$. e., this action becomes restricted to the use of a space where numbers should be plotted and curves should be traced, with no concerns about which one is the independent variable (domain), supposed to be in the x-axis, and which one should be represented in the y-axis (the dependent variable - image), and most importantly, the phenomenon represented in the graphic. 
Similarly, about $30 \%$ of the students establish the reason for scale choice as for the ease of understanding, while a significant portion (about 48\%) did not present any justification, which might indicate that they do not comprehend what this means.

In short, these results show us indications that students construct their graphics as simple illustrations, and that their approaches to do this is based mainly in the implicit aspects, which places them in the most superficial levels of comprehension of this kind of mathematical objects. An example of this way of thinking is displayed in Figure 1.

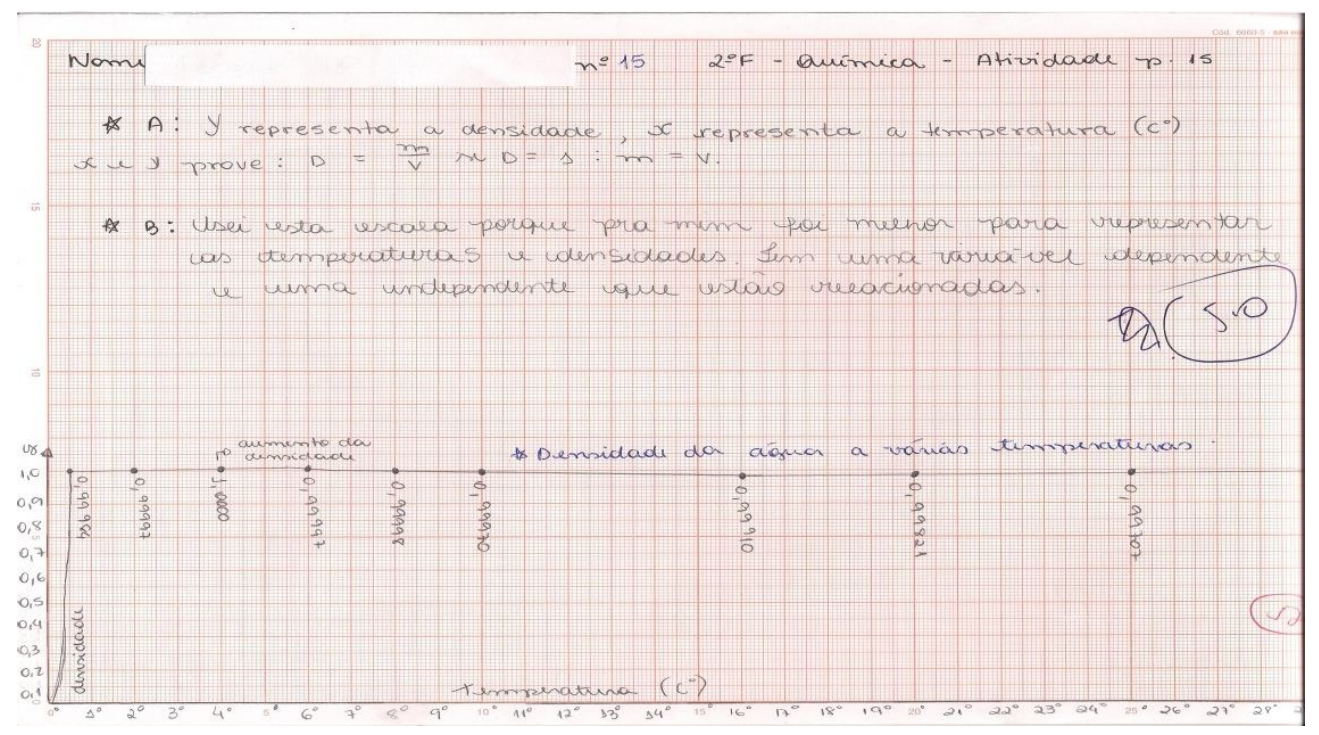

Figure 1. Graphic constructed by a student. Answer to question A: "Y represents the density, $X$ represents the temperature $(C) ; X$ e Y proves: $D=m / V$, if $D=1, m=V$." Answer to question B: "I used this scale because to me it was better to represent the temperatures and densities. There is a dependent variable and an independent one which are related."

The graphic shown in Figure 1 represents the typical construction in which the student solely plots the values at $\mathrm{x}$ - and $\mathrm{y}$-axis using as a reference the divisions from the graph paper. It is possible to notice that 0 is the numeric value for the density of water at 0 ${ }^{\circ} \mathrm{C}$, and it does not allow the observation of a positive growing change of density between 0 to $4{ }^{\circ} \mathrm{C}$ and its further decrease.

The recent literature on research in Chemistry classroom is concerned with how students transit through the different forms of representations, and many studies indicate that teachers must focus their attentions in the search for mechanisms that might help in this task. Similarly, a recent study (Dias De Souza, Moreira \& Arroio, 2012b) indicates that although students are able to build graphics associated with phenomena, this construction is fulfilled with the common sense, only reproducing what the teacher does.

This way of thinking and acting leads students to not consider important aspects in the construction of these representations, such as inserting a title and the unities of variables in $\mathrm{x}$ and $\mathrm{y}$ axes, correctly assign domain and image of a function, and giving little attention to the proportionality among intervals at the axes, which as a result impose restrictions that make difficult the suitable representation of a phenomenon in the form of a 
graphic, as exemplified in Figure 2, where the student have not considered the important elements, compromising so the representation of the studied phenomenon.

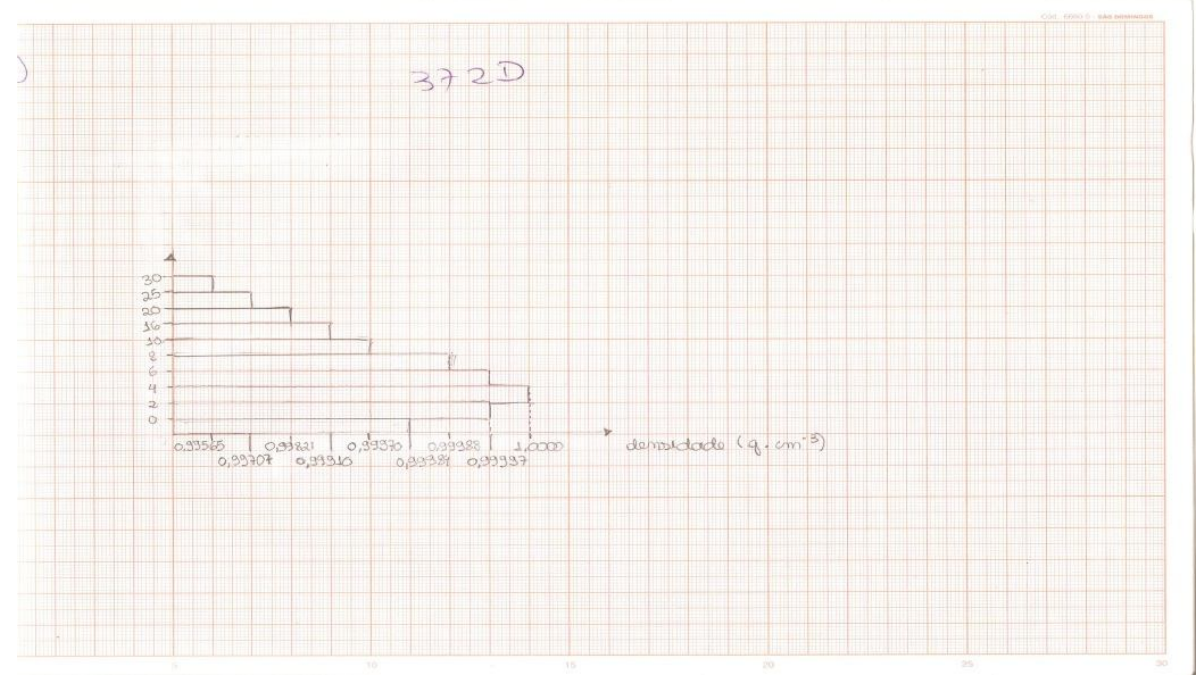

Figure 2. An example of a graphic constructed without considering all the important elements for a suitable visualization of the dependence of density with temperature.

Knowing these restrictions, the teacher may organize the activities in the classroom in such a way that helps students to overcome the superficial patterns of reading and interpretation, elevating them to a level that allows the establishment of relations among interpreting, explaining and predicting the phenomena represented by graphics.

\section{Analysis of the Official State and National Curriculum Documents}

The analysis of National Curriculum Orientations for High School (Brasil, 2006, p.104) in the fields of Math and Natural Sciences reveals that the term "graphics" is cited predominantly for Math teaching, being cited only one time for Chemistry teaching. These citations for Chemistry make part of a critical analysis of the results for the High School National Examination (ENEM), which points out the difficulties of students to interpret graphics:

“(...) Students have not managed to produce coherent answers from data sets that demand interpretation, reading of tables, charts and graphics, and are not able to make comparisons or to justify their judgments" (Brasil, 2006, p. 104).

The general orientation found in this official document is that the teacher is supposed to develop graphical interpretation with their students, but there is no reference to the need of practicing with their students the elements involved in the construction of graphics.

On the other hand, the orientations from the State of Sao Paulo Secretary of Education (SEE/SP) for Math teaching declares that "everyone deals with numbers, measurements, forms and operations; everyone read and interpret texts and graphics(...)", and 
cites technological resources "(...) the software to construct graphics", stimulating the insertion of analytical geometry concepts at elementary/middle school, indicating that these concepts "(...) might - and must - be associated to the construction, analysis and interpretation of graphics".

Beginning the discussion by elementary/middle school, Table 2 presents the relations between grades/years, categories, contents and skills that must be elaborated in Math classes at this level.

Table 2. Contents related to graphic construction to be treated in Math classes of elementary/middle school according to SEE/SP orientations.

\begin{tabular}{|c|c|c|c|c|}
\hline Grade/year & Bimester & Category & Contents & Skills \\
\hline $\begin{array}{l}5^{\text {th }} \quad \text { grade } / 6^{\text {th }} \\
\text { year }\end{array}$ & $4^{\text {th }}$ & $\begin{array}{l}\text { Num- } \\
\text { bers/relations }\end{array}$ & $\begin{array}{l}\text { Reading and con- } \\
\text { struction of graphics } \\
\text { and tables }\end{array}$ & $\begin{array}{l}\text { Knowing how to construct } \\
\text { elementary graphics (bars, } \\
\text { lines and points), using proper } \\
\text { scales. }\end{array}$ \\
\hline $\begin{array}{ll}6^{\text {th }} & \text { grade } / 7^{\text {th }} \\
\text { year } & \end{array}$ & $3^{\text {rd }}$ & Relations & $\begin{array}{l}\text { Construction of } \\
\text { graphics of sectors }\end{array}$ & $\begin{array}{l}\text { Recognizing and knowing } \\
\text { how to use the concept of } \\
\text { ratio in different contexts } \\
\text { (proportionality, scale, rate, } \\
\text { percentage), as well as in } \\
\text { graphics of sectors. }\end{array}$ \\
\hline $\begin{array}{l}7^{\text {th }} \quad \text { grade } / 8^{\text {th }} \\
\text { year }\end{array}$ & $3^{\text {rd }}$ & $\begin{array}{l}\text { Num- } \\
\text { bers/relations }\end{array}$ & $\begin{array}{l}\text { Graphics and coor- } \\
\text { dinates: localization } \\
\text { of points in the Car- } \\
\text { tesian plane }\end{array}$ & $\begin{array}{l}\text { Understanding and using the } \\
\text { Cartesian plane to represent } \\
\text { ordered pairs, as well as to } \\
\text { represent solutions for a sys- } \\
\text { tem of linear equations. }\end{array}$ \\
\hline $\begin{array}{l}8^{\text {th }} \quad \text { grade } / 9^{\text {th }} \\
\text { year }\end{array}$ & $2^{\text {nd }}$ & $\begin{array}{l}\text { Num- } \\
\text { bers/relations }\end{array}$ & $\begin{array}{l}\text { Construction of } \\
\text { graphics and tables } \\
\text { to represent func- } \\
\text { tions of first and } \\
\text { second degrees }\end{array}$ & $\begin{array}{l}\text { Knowing to construct } \\
\text { graphics of functions of first } \\
\text { and second degrees by means } \\
\text { of tables comparing graphics } \\
\text { of functions } y=x \text { and } y=x^{2} \text {. }\end{array}$ \\
\hline
\end{tabular}

In short, the state of Sao Paulo official curriculum indicates in a sparse and relatively superficial form some teaching practices related to the development of the competence of constructing graphics, usually referring to a formal mathematical description.

A direct consequence of this conception reflects in the discussions about the concepts of scales, domain, image, variable and magnitude, which either do not appear at any moment, or are only occasionally cited. The concept of proportionality that is associated to scale appears in a very general manner, mainly in the perspective of formal mathematics.

This corroborate the results of the questionnaire applied to students, in which they claim to have learned to construct graphics with their Math teachers, at elementary school (especially $6^{\text {th }}$ grade $/ 5^{\text {th }}$ year), and that they construct graphics by simply dividing the axes in identical proportions independently of the data in hand, and by plotting the numeric values in ascending order at each annotated division. Additionally, referring to the axes corresponding to the domain and image of a function, they took as a reference to plot in the x-axis (domain) the location of the set of numbers in the table provided, which means that the first set that appears in the table is for sure the $\mathrm{x}$-axis, while the next one must be plotted in the y-axis.

Table 3 shows us the relations between grades/years, categories, contents and skills that must be handled in Math at the high school level. 
Table 3. Contents related to graphic construction to be treated in Math classes of high school according to SEE/SP orientations.

\begin{tabular}{|l|l|l|l|l|}
\hline Grade & Bimester & Category & Contents & Skills \\
\hline $2^{\text {nd }}$ & $1^{\text {st }}$ & Relations & Trigonometry & $\begin{array}{l}\text { Knowing to construct the graph- } \\
\text { ic of trigonometric functions } \\
\text { such as } \mathrm{f}(\mathrm{x})=a \text { sen }(b \mathrm{x})+c, \text { from } \\
\text { the graphic of y sen x, com- } \\
\text { prehending the meaning of trans- } \\
\text { formations associated to coeffi- } \\
\text { cients } a, b \text { and } c .\end{array}$ \\
\hline $3^{\text {rd }}$ & $1^{\text {st }}$ & Relations & $\begin{array}{l}\text { Study of func- } \\
\text { tions }\end{array}$ & $\begin{array}{l}\text { Knowing to construct graphics } \\
\text { of functions by means of trans- } \\
\text { formations into simpler func- } \\
\text { tions (horizontal and vertical } \\
\text { translations, symmetries, inver- } \\
\text { sions). }\end{array}$ \\
\hline $3^{\text {rd }}$ & $4^{\text {th }}$ & $\begin{array}{l}\text { Num- } \\
\text { bers/relation } \\
\mathrm{s}\end{array}$ & Statistics & $\begin{array}{l}\text { Knowing to construct and inter- } \\
\text { pret tables and graphics of fre- } \\
\text { quency, from data obtained in } \\
\text { researches by statistic sampling. }\end{array}$ \\
\hline
\end{tabular}

The word "graphic" in the Natural Sciences curriculum at the high school level appears usually associated to the skills of reading, interpretation, identification and establish relations, and in a single moment appears the skill of "construction", located in the section dedicated to the first grade of Biology: "Constructing representative graphics of the situation of health in different regions".

The term "scale" appears in the Natural Sciences curriculum of elementary/middle school in different occasions: $5^{\text {th }}$ grade: associated to the skills of "representing in scale, by means of charts and schemes, the different layers of the Earth"; $6^{\text {th }}$ grade: "(...)distances and sizes at the solar system", "constructing a model in scale of the solar system" and "interpreting the relations between sizes and distances among its stars"; 8 th grade: "making use of proper scales to represent the electromagnetic spectrum".

The terms "domain of a function", image of a function", "variable", and "magnitude" do not appear a single time in the Natural Science curriculum.

\section{Semistructured Interview}

The teacher interviewed, named here as Vilma, has ended her teaching education graduation in Math and Sciences Math teaching specialization at the eighties, she is 57 years old and has been working as a high school teacher for more than 25 years.

Before the start of the interview, Mrs. Vilma, when asked about her will to discuss the issue of graphics, exclaimed: "I didn't understand what you are talking about the students not being able to construct graphics at the $3^{\text {rd }}$ grade of high school (at the same time, she draws a pair of perpendicular axes and traces a curve to illustrate her speech, as shown in Figure 3)...this year I'm teaching $2^{\text {nd }}$ graders and I started to make a revision of functions of second degree, in order to do a diagnostic evaluation. I began with a first degree function and discovered that they have no clue on what is domain or image, you 
give them a table and they think it is simply to put on the first column in the x-axis, and

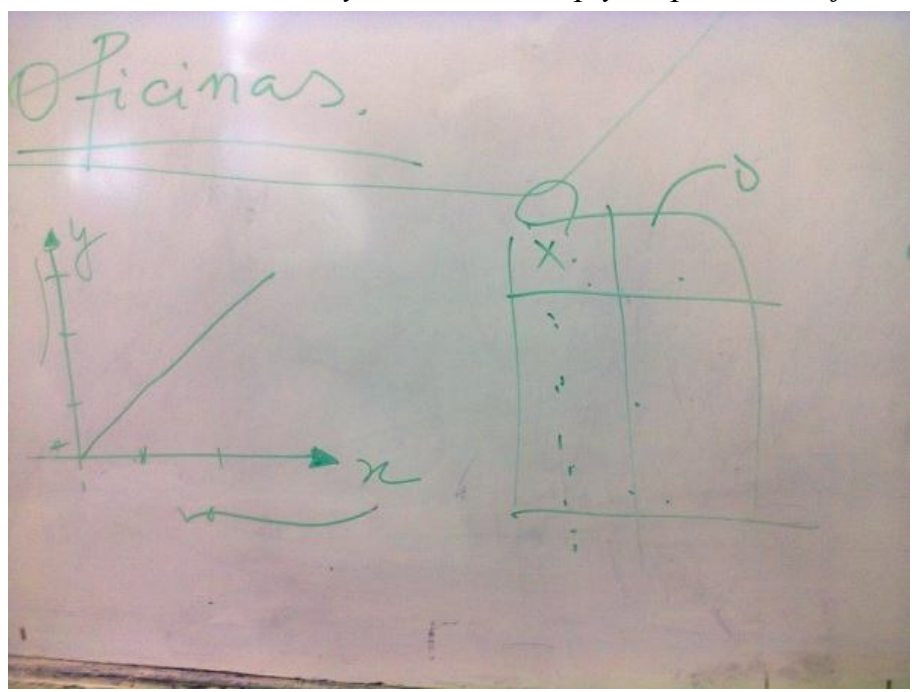

it's done."

Figure 3: Drawing produced by Vilma during the interview in order to illustrate her speech about graphics.

Then, Mrs. Vilma expresses how hard it is for the students to establish a relation between the two sets of variables: "They don't know where these values of $x$ and $y$ come from...even less that this is obtained by an experiment, they don't know the science involved or the mathematical relation between them."

This comment makes clear that the teacher comprehends that there are two domains involved in the study of graphics, the experimental data and the symbolic/formal domain of mathematics, which requires specific treatments.

Continuing her speech, Mrs. Vilma explains that “(...) students divide the $x$ and $y$ axes of the chart with the same intervals and plot the values drawing a straight line 45, because they put the intervals at a ratio of 1 to 1, for example if the values are 10:50 they pose the same range of $1 \mathrm{~cm}$ to represent the value 10 and the value 50. I watched part of it making an OT (Technical Guidance) on the Board of Education, where I heard Math teachers speaking there are no problems in dividing the axes at the same intervals".

Retaking the interview, the researcher asks the teacher about her conceptions on the values of images over words in the contemporary society, and she answers: "for people in the field of Math this is difficult...but I agree and consider a value of 10 to words and 9 to images", implying that she admits the importance of content over the image, which should naturally be translated into teaching practices.

Next, the teacher was questioned about the formal studies at her workplace on the contents of national and state official curriculum documents, and about the use of these documents for scholar planning along the results of diagnostic evaluations. She informed that there was no systematic debate about this, but only in a special occasion called Technical Orientation (TO) she took part. Furthermore, she emphasizes that the debate about planning based on diagnostic evaluations occurs "only between the left and right sides of the brain", but never with the other teachers: "when we have planning meetings, we don't manage to have a line of thought, our mathematical vision, the teacher's visions on Math and teaching in general in the exact sciences is too traditional." 
It understands as the traditional use of didactic books as a reference to annual scholar planning, focusing on formal and descriptive Math, with an end in itself and without making associations with other disciplines.

Finally, the interview was conducted towards getting to know how graphics are taught in the classroom, which was answered as: “(...) I always use graphic paper in the first place, then I speak about scale and proportion, you know? I start with ratio and proportion, I think this comes from when I coursed three years of Civil Engineering, in the Physics' chair, this was the only time I was taught how a graphic must be constructed...in Math graduation I never studied the construction of graphics in scale, but I think this way of teaching is quite restricted, and this is exactly why I started to go to the TOs, because I can't see the graphics without speaking of scale."

At last, some indications can be extracted from this interview, which show the continuity of teaching practices exclusively turned to strategies that induce students to face the proposed problems as simple routine exercises and to retain enormous quantities of memorizable information, not adding up to promote significant knowledge that may contribute to the process of scientific literacy, especially related to graphical literacy.

\section{Conclusions}

These findings indicate that graphics are treated at public schools in a descriptive manner, within the scope of Math curriculum and relegated to a second plane in the Natural Science curriculum.

Usually, the presentation of graphics is performed based on a function or from a table of ordered pairs of data. In its turn, scientific data is a product of observation and collection, the assignment of axes and the choice of scales, meaning that the mechanical construction of graphics within Math classes do not allow students to make it in a different perspective or occasion, as in the case of investigative activities at Chemistry classes.

The assignment of values in intervals of Cartesian axes, referred as scales, and the decision on which data goes to which axes, are part of the required knowledge to the scientific and investigative work, besides the fact that the units of measurements are an issue of situated context, as in the case of the present study, which lies in the domains of physical-chemistry.

In Chemistry investigative activities, the selection and construction of scales is a problem of particular relevance, since its inadequacy may cover or distort trends, compromising the possible inferences on final results. In the official documents, and even in the general literature on education, it is possible to observe an antagonistic landscape, since despite the vital role that scale definition plays in the construction and interpretation of graphics, and how the reading and interpretation of graphics is considered as a relevant skill, the teaching of this content is rarely approached in these documents, and so, is neglected in Math and Natural Science practices in the classroom.

The initial hypothesis that regarded the official documents as the generators of diffuse orientations that might justify the teaching practices observed and the restrictions exhibited by students while constructing graphics gains weight, since according to our findings, the issue has its core localized in the initial teacher training, which naturally requires further investigations.

In other words, the results obtained display a final picture produced by students when solving investigative problems, which has its origin in teaching training, gain a certain status when it is not approached in official curriculum documents, reflects itself in classroom practices of descriptive and formal aspects of mathematics, and with teachers 
of other Natural Sciences disciplines relegating to a secondary plane the required specific handling of this topic, which all implicate in significant restrictions in students' learning.

This is an important indicative to the constructors of teaching training curriculum in the field of Math and Natural Sciences, since it is of plenary social and academic recognition the vital importance of concerns about graphical literacy.

\section{References}

Anderson, R. F., \& Helstrup, T. (1993). Visual discovery in mind and on paper. Memory and Cognition, 21 (3), 283-293.

Arroio, A. (2011). Cinema as narrative to teach nature of science in science education. Western Anatolia Journal of Educational Sciences, Special Volume, 87-92.

Arroio, A., \& Dias de Souza, D. D. (2012). Multimodality in science education. Problems of Education in the 21st Century, 44, 5-9.

Barro, M.R., Ferreira, J.Q., \& Queiroz, S.L. (2008). Blogs: aplicação na educação em química. Química Nova na Escola, 30, 10-15.

Bastide, F. (1990). The iconography of scientific texts: principles of analysis. In Lynch, M. \& Woolgar, S. (Eds.). Representation in Scientific Practice. Cambridge, MA: MIT Press, p. 187-229.

Berg, C. A, \& Smith, P. (1994). Assessing students' abilities to construct and interpret line graphs: disparities between multiple-choice and free-response instruments. Science Education, 78 (6), 527-554.

Betrancourt, M., Ainsworth, S., De Vries, E., Boucheix, J. M., \& Lowe, R. K. (2012). Graphicacy: do readers of science textbooks need it?. In EARLI SIG 2 Meeting 2012, Grenoble, France: Universite Pierre-Mendes-France.

Boucheix, J. M., Lowe, R. K., Ainsworth, S., Betrancourt, M., \& De Vries, E. (2012). Paired graphics: an exploratory study of graphicacy. In EARLI SIG 2 Meeting 2012, Grenoble, France: Universite Pierre-Mendes-France.

Brasil (2006). Ministério da Educação. Secretaria de Ensino Médio e Tecnológico. Orientações curriculares para o ensino médio: ciências da natureza, matemática e suas tecnologias. Brasília: MEC/SEMTEC.

Bybee, R. W. (2013) STEM education Challenges and opportunities. National Science Teachers Association. 111p.

Camargo Filho, P., Laburu, C., \& Barros, M. (2011) Dificuldades semióticas na construção de gráficos cartesianos em cinemática. Caderno Brasileiro de Ensino de Física, 28 (3), 546-563.

Chassot, A. (2003). Alfabetização científica: questões e desafios para a educação. Ijuí: Unijuí.

Crosland, M. (1962). Historical studies in the language of chemistry. Cambridge, MA: Harvard University Press.

De Vries, E., \& Lowe, R. K. (2010). Graphicacy: What does the learner bring to a graphic? In SIG2 - 2010: Comprehension of text and graphics. Tracing the mind: how do we learn from text and graphics? Tuebingen Germany: Knowledge Media Research Centre.

Dias de Souza, D. D., Moreira, M. F., \& Arroio, A. (2012a). The multimodal learning as a strategy for chemistry representation conversion: The phenomenon to the chart. Gamtamokslinis ugdymas / Natural Science Education, 35, 20-31.

Dias de Souza, D. D.; Moreira, M. F., \& Arroio, A. (2012b) Caracterizando gráficos construídos por estudantes de ensino médio em salas de aula de química. In: $32^{\circ} \mathrm{En}$ contro de Debates Sobre o Ensino de Química - EDEQ, 2012, Porto Alegre. EDEQ. 
Duval, R. (2003). Registros de representações semiótica e funcionamento cognitivo da compreensão em matemática. In: Machado, S.D.A. (Org.) Aprendizagem em matemática: registros de representação semiótica. Campinas, São Paulo: Papirus. 11- 33.

Duval, R. (2009). Semiósis e pensamento humano: registro semiótico e aprendizagens intelectuais. São Paulo: Livraria da Física.

Garcia Garcia, J. J. (2005). La comprensión de las representaciones gráficas cartesianas presentes en los libros de texto de Ciencias Experimentales, SUS características y el uso que se hace de ellas en el aula. Memoria de tesis doctoral. Universidad de Granada. España.

Giordan, M. (2008) Computadores e linguagens nas aulas de ciências. Ijuí: Ed. Unijuí. 328 p.

Harrison, G. A. \& Treagust, F. D. (2000). A typology of science models. International Journal of Science Education, 22, 9, 1011-1026.

Hoffmann, R., \& Laszlo, R. (1991). Representation in chemistry. Angewandte Chemie, 30,116.

Illman, D. (1994). Multimedia tools gain favor for chemistry presentations. Chemical and Engineering News, 72, 34-40.

Kintsch, W. (1998). Comprehension: a paradigm for cognition. Nova York: Cambridge University Press.

Kozma, R. B. \& Russell, J. (1997) Multimedia and understanding: Expert and novice responses to different representations of chemical phenomena. Journal of Research in Science Teaching, 34 (9), 949-968.

Kozma, R., Chin, E., Russell, J., \& Marx, N. (1997). The roles of representations and tools in the chemistry laboratory. (Tech. Rep.). Menlo Park, CA: SRI International.

Leinhart, G.; Zaslavsky, O., \& Stein, M. K. (1990). Functions, graphs, and graphing: tasks, learning, and teaching. Review of Educational Research, 60 (1), 1-64.

Lemke, J. L. (1998a). Qualitative research methods for science education. In: Fraser, B. J.; Tobin, K. G. (Eds.). International handbook of science education. v. 2, p. 1175-89. Dordrecht, The Netherlands: Kluwer Academic Publishes.

Lemke, J. L. (1998b). Multiplying meaning: visual and verbal semiotics in scientific text. In: Martin, J. R. \& Veel, R. (Eds), Reading Sciences, p. 87-113.

León, J. A. (1999). Mejorando la comprensión y el aprendizaje del discurso escrito: estrategias del lector y estilos de escritura. In: Pozo, J.y Monereo, C. El aprendizaje estratégico. Madrid. Santillana. p. 153-169.

Mello, I. C. (2009). O ensino de química em ambientes virtuais. Cuiabá: EdUFMT, 294p.

Merino, N., \& Cerezo, J. (2012). Cultura científica para la educación del siglo XXI. Revista Iberoamericana de Educación, 58, 35-59.

Moraes, R., \& M. C. Galiazzi. (2007). Análise textual discursiva. Ijuí: Unijuí.

Nass, D. P. (2008). Gráficos como representações visuais relevantes no processo ensino- aprendizagem: uma análise de livros didáticos de química do ensino médio. Dissertação (Mestrado em Química Analítica) - Instituto de Química de São Carlos, Universidade de São Paulo. Retrieved February 23, 2013, from http://www.teses.usp.br/teses/disponiveis/75/75132/tde-11092008-151037/>.

Mortimer, E. F. (1998). Sobre chamas e cristais: a linguagem cotidiana, a linguagem científica e o ensino de ciências. In: Chassot, A., \& Oliveira, R.J (Orgs.). Ciência, ética e cultura na educação. São Leopoldo: Ed. UNISINOS.

Postigo, Y., \& Pozo, J. (1999). Hacia una nueva alfabetización: el aprendizaje de información grafica. In: J. P. (Coords.), El aprendizaje estratégico: enseñar a aprender desde el curriculo. Madrid: Santillana, p. 251-267.

Postigo, Y., \& Pozo, J. (2000). Cuando una grafica vale más que 1.000 dados: la interpretación de graficas por alumnos adolescentes. Infancia y Aprendizage, 90, 89110. 
Roth, W. (2002). Reading graphs: contributions to an integrative concept of literacy. Journal of Curriculum Studies, 34 (1), 1-24.

Schnotz, W., Bannert, M. (2003). Construction and interference in learning from multiple representations. Learning and Instruction, 13 (2), 141-156.

Secretaria Estadual De Educação/São Paulo - SEE/SP. (2010). Relatório Pedagógico SARESP. São Paulo: FDE.

Received 09 November 2013; accepted 10 December 2013

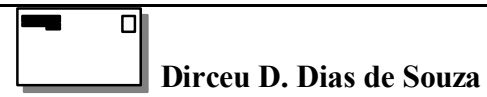

Adjunct Professor, Chemistry Department, Federal University of Paraiba, João Pessoa, Brazil.

E-mail:baumcima@yahoo.com.br

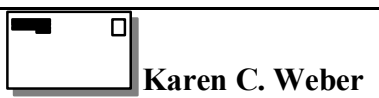

Adjunct Professor, Chemistry Department, Federal University of Paraiba, João Pessoa, Brazil.

E-mail: karen@quimica.ufpb.br

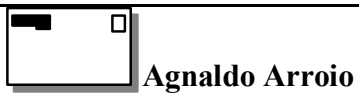

$\mathrm{PhD}$, Associate Professor, University of Sao Paulo, Faculty of Education, Av. da Universidade 308, bloco A, sala 109., Butantã, 05508-040 São Paulo - SP - Brazil

E-mail: agnaldoarroio@yahoo.com

Website: http: / / usp-br.academia.edu / AgnaldoArroio 